\title{
Ultrastructural demonstration of different peroxidase activities during the bean rust infection process
}

\author{
Kurt Mendgen \\ Institut für Pfanzenpathologie und Pfanzenschutz der Universität Göttingen, \\ 34 Göllingen, Federal Republic of Germany
}

(Accepled for publication January 1975)

During penetration and infection of the bean leaf by the rust fungus, at $22 \mathrm{~h}$ after artificial inoculation, the following sites of peroxidase activity were observed which might influence, the interaction of the host and parasite:

(1) The guard cell walls of the stoma are covered with a layer that shows peroxidase activity. This activity might influence the infection peg of the fungus.

(2) Within the leaf, the infection hypha of the bean rust fungus contacts a layer of peroxidase activity at the outer surface of the host cells. In the compatible combination employed, no differences in the peroxidase activity at this site were detected between cells which came in contact with hyphae and those which did not.

(3) The penetration peg of the haustorial mother cell enters the host cell and differentiates to form the haustorial neck. Here, a very strong peroxidase activity was observed, which might be a defence reaction of the host against the pathogen.

(4) During the development of the haustorial body, peroxidase activity was seen on the rough endoplasmic reticulum and in the Golgi bodies. It is suggested that peroxidase is synthesized on the endoplasmic reticulum and secreted towards the partly invaginated sheath by the Golgi bodies. cells.

(5) Peroxidase activity was observed on the nuclear envelope of some nuclei in infected

\section{INTRODUCTION}

It seems to be well established that an increase of peroxidase activity can be measured in homogenates of bean leaves some days after infection with viruses $[2,6,33]$, bacteria [27] and bean rust $[21,22,36]$. These studies were made either by measuring the total peroxidase activity in extracts or by separating proteins by gel electrophoresis and staining of bands for enzyme activity. After incubation of bean rust infected leaves with 3,3'-diaminobenzidine, the ultrastructural localization of the oxidized substrate indicated peroxidase activities on the outside of the cell wall, on the haustorial neck at the site of fungal penetration and sometimes on the ribosomes of the endoplasmic reticulum around the haustorium [20].

Recent electrophoretic studies [21] show that only a temporary increase of some peroxidase isoenzymes occurs during the first $24 \mathrm{~h}$ after infection.

The purpose of this study was to investigate: (1) whether the increase of peroxidase activity is a contribution of the host or the pathogen; (2) if this enzyme influences the fungal penetration in the leaf as well as the formation of the first haustorium within the leaf cells; and (3) whether synthesis of peroxidase occurs in particular cell organelles during infection. 


\section{MATERIALS AND METHODS}

Bean plants (Phaseolus vulgaris, cv. "Favorit") were grown in compost soil at $21{ }^{\circ} \mathrm{C}$ under approximately $4000 \mathrm{~lx}$ incandescent light for $16 \mathrm{~h} /$ day. Ten days after sowing, all but the primary leaves were removed. These leaves were then coated with a washed spore suspension of Uromyces phaseoli (Pers.) Wint. var. typica Arth. and inoculated under high humidity conditions. Twenty-two hours later, pieces of infected tissue $(0.5 \times 2 \mathrm{~mm})$ were fixed for $1 \mathrm{~h}$ at $20^{\circ} \mathrm{C}$ in $3.5 \%$ glutaraldehyde in $0.08 \mathrm{~m}$-cacodylate buffer ( $\mathrm{pH} 7 \cdot 1$ ), containing $2 \%$ sucrose. The tissue was vacuum infiltrated and stirred to ensure rapid penetration of the fixative. After $8 \mathrm{~h}$ washing in the sucrose buffer mentioned above, the material was incubated in one of the following media:

Medium I for demonstration of peroxidase and catalase (peroxidatic) activity, modified after Novikoff \& Goldfischer [23]: $20 \mathrm{mg}$ diaminobenzidine (DAB) were dissolved in $9.8 \mathrm{ml} 0.05 \mathrm{M}$-aminopropandiol, $0.2 \mathrm{ml}$ of $1 \% \mathrm{H}_{2} \mathrm{O}_{2}$ was added and the mixture adjusted to $\mathrm{pH} 9$.

Medium II for demonstration of peroxidase and cytochrome oxidase (peroxidatic) activity, modified after Novikoff \& Goldfischer [23]: $20 \mathrm{mg}$ DAB were dissolved in $9.9 \mathrm{ml} 0.05 \mathrm{M}$-acetate buffer, $\mathrm{pH} 5,0.1 \mathrm{ml}$ of $1 \% \mathrm{H}_{2} \mathrm{O}_{2}$ was added and the mixture adjusted to $\mathrm{pH} 6$.

Medium III for demonstration of peroxidase, cytochrome oxidase (peroxidatic) and catalase (peroxidatic) activity [18]: $20 \mathrm{mg}$ DAB were dissolved in $10 \mathrm{ml}$ $0.05 \mathrm{M}$-Tris- $\mathrm{HCl}$ buffer $\left(\mathrm{pH} 7.5\right.$ ) containing $4 \%$ sucrose, $0.05 \mathrm{ml}$ of $1 \% \mathrm{H}_{2} \mathrm{O}_{2}$ was added and the mixture adjusted to $\mathrm{pH} 7 \cdot 5$.

For inhibition studies, leaf samples were washed in buffer and then incubated in media containing either 0.02 $\mathrm{m}$-3-amino-1,2,4-triazole (Fluka) to inhibit catalase activity or $0.02 \mathrm{~m}$-potassium cyanide to inhibit peroxidase and cytochrome oxidase activity. To inhibit all enzyme activity, samples were heated for 2 min at $98{ }^{\circ} \mathrm{C}$ before incubation or $\mathrm{H}_{2} \mathrm{O}_{2}$ was omitted from the incubation media.

Preparation of the incubation media, as well as incubation of the material, was done in the dark. Incubation media remained clear and did not stain red-brown.

After incubation for $1 \mathrm{~h}$ at $37^{\circ} \mathrm{C}$, the material was washed in $0.08 \mathrm{M}$-cacodylate buffer $(\mathrm{pH} 7 \cdot 1)$ containing $4 \%$ sucrose, and then postfixed in $2 \%$ osmic acid in the same buffer at $2{ }^{\circ} \mathrm{C}$ overnight. After washing thoroughly in the buffer, the samples were dehydrated in graded ethanol series, treated with propylene oxide and embedded in Spurr's epoxy resin [34]. Cross-sections were examined in the light microscope with interference optics (Leitz Interferenzkontrast) and the growth of a selected infection hypha was followed. Ultra-thin sections were cut at selected places with a Reichert OM U III ultramicrotome and examined without counterstain with a Zeiss EM $9 \mathrm{~S}$ or a Philips 301 electron-microscope.

The Plates reported in this study were taken from material incubated in Medium III, whereas the other media were used to characterize the enzyme activities.

\section{RESULTS}

Fungal penetration of the leaf

Before the bean rust penetrates the leaf, its germ tube forms an appressorium the lower side of which moulds into the folds of the outer ledge of the stoma [19]. Thus, 
the appressorium is fixed on the stoma when the infection peg pushes the guard cells apart. The localized growth of the appressorium underside leads to the formation of the infection peg. The fungal cytoplasm passes through the infection peg and the substomatal vesicle is formed in the substomatal chamber.

During this close contact with the guard cells, the fungus has to touch a prominent layer with peroxidase activity that covers the outside of the guard cell walls (Plate l). Although we observed in most instances that the infection peg does not seem to be influenced by the layer on the stomatal wall with peroxidase activity (Plate 2), some infection structures were found to contain dark deposits in the infection peg indicating peroxidase activity (Plate 3). Since we did not on any occasion detect peroxidase activity elsewhere in the cytoplasm of the fungus, it is not certain whether this activity is of fungal origin or indicates some part played by the host by secreting wall peroxidases.

The enzyme activity on the guard cell walls was observed in all three media used. It could be greatly reduced by addition of $\mathrm{KCN}$ to the media and was not observed after heat treatment of the samples or omission of $\mathrm{H}_{2} \mathrm{O}_{2}$ from the incubation media.

\section{Penetration of the host cell}

The substomatal vesicle elongates and forms the infection hypha, at the tip of which the haustorial mother cell is differentiated. The haustorial mother cell closely touches the host cell.

In most cases, the outer surface of the host cells is covered with a layer possessing strong peroxidase activity (Plate 7 ). Sometimes, this layer is very faint (Plate 4 ). The infection hypha, and especially the haustorial mother cell, is in close contact with this layer. It seems that the layer with peroxidase activity is not changed after being in contact with the fungus (Plate 7). No obvious difference could be found between these walls compared to other parts of the host cell walls which had not come in contact with the parasite. The haustorial mother cell seems to dent the host cell wall (Plate 4) thus indicating some mechanical pressure by the fungus.

In a very restricted area of the haustorial mother cell, the penetration peg develops, penetrates the host cell wall, elongates and forms the neck of the haustorium [see $15,16,19$ and the references cited therein].

The layer on the host cell wall with peroxidase activity is perforated only at the penetration site of the penetration peg and may even touch the plasma membrane of the fungus (Plate 6). Plate 4 shows an early stage of haustorial neck formation. Although the layer on the host cell wall with peroxidase activity can hardly be seen, intense activity on the haustorial neck is evident (Plate 4). The extent of this enzyme activity can be estimated in a longitudinal section through a complete haustorial neck (Plates 6 and 7). There seems to be no spatial connection between the peroxidase on the cell wall and the peroxidase activity on the haustorial neck. The activity on the wall of the haustorial neck is restricted in length to about two-thirds of the haustorial neck and is bounded by the host-and parasite-plasma membrane respectively (Plate 6).

As reported in our earlier study on the first bean rust haustorium [19], no neckband was found on the haustorial neck. However, 3 days after infection, haustoria 
had neckbands $[9,20]$ and the peroxidase activity on the haustorial neck reached up to the neckband [20].

At the distal end of the haustorial neck develops the haustorial body. A sheath separates the wall of the haustorial body from the surrounding invaginated host plasma membrane. A cross-section through the haustorial neck showing peroxidase activity and the haustorial body surrounded by its sheath (Plate 5) emphasizes not only the structural difference of these parts of the haustorium, but also suggests a functional difference.

The enzyme activity on the haustorial neck was observed after incubation in all three media. It could be inhibited with $\mathrm{KCN}$, but not with aminotriazole. After heat treatment, the dark deposit of oxidized $\mathrm{DAB}$ was absent. This corresponds to our earlier results [20].

Reactions of the host cell

Rough-surfaced endoplasmic reticulum encircles the young haustorium [19]. The cisternae are often flattened and sometimes in contact with the host plasma membrane $[9,10,16]$. Golgi bodies and associated vesicles also appear-although they are not particularly abundant - in the neighbourhood of the haustorial body.

After incubation in the three media used, all the Golgi bodies which were found around haustoria contained peroxidase activity (Plate 8 ). Their vesicles embody enzyme activity that seemed concentrated on the membranes (Plates 9 and 10). The vesicles were obviously secreted towards the partly invaginated sheath of the young haustorium (Plate 10). Around the haustorium and especially in the neighbourhood of the Golgi bodies, peroxidase activity was seen on the rough endoplasmic reticulum (Plates 9 and 11).

All the nuclei observed were found close to haustoria. The nuclear envelope of a few nuclei showed staining due to peroxidase activity (Plate 11).

Very few cells showed the necrotic reactions (Plate 12) which we have observed in incompatible bean varieties (to be published). In the necrotic cells of this compatible combination, the host cytoplasm indicated DAB staining whereas the plastids and the haustorium appear normal (Plate 12). We could not make inhibitor studies with these cells, since in material treated with heat or KCN no such cell could be found. Either such cells were absent in the material or the enzyme activity was completely inhibited. Necrotic cells have also been observed during a light microscopical study of the stem rust infection process [32] in a compatible combination.

In infected and uninfected cells, peroxidase activity on the membrane of the vacuole and on the walls could be found after incubation in all three media. The enzyme activity was sensitive to $\mathrm{KCN}$ and was absent after heat treatment or omission of $\mathrm{H}_{2} \mathrm{O}_{2}$ from the incubation media. In contrast to peroxidase activity, staining on mitochondrial membranes could be found only after incubation in Medium II and Medium III. Staining was absent after addition of KCN or heat treatment, but was very weak after omission of $\mathrm{H}_{2} \mathrm{O}_{2}$ from the media. Staining in peroxisomes was observed after incubation in Medium I and Medium III and was absent after addition of aminotriazole or heat treatment. This corresponds to our earlier results $[17,18,20]$. 


$\begin{array}{ll}\text { bc } & \text { back cavity } \\ \mathrm{c} & \text { cuticle } \\ \mathrm{er} & \text { endoplasmic reticulum } \\ \mathrm{fc} & \text { front cavity } \\ \mathrm{g} & \text { Grolgi body } \\ \mathrm{gc} & \text { guard cell } \\ \mathrm{ha} & \text { haustorium } \\ \mathrm{hn} & \text { haustorial neck } \\ \mathrm{hmc} & \text { haustorial mother cell } \\ \mathrm{hc} & \text { host cytoplasm } \\ \mathrm{il} & \text { inner ledge }\end{array}$

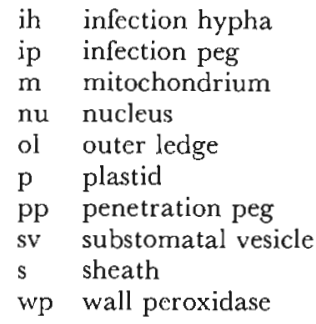

Plate 1. Gross-section of a stoma in a non-infected bean leaf. In the front cavity ( $\mathrm{fc}$ ) and in the back cavity (bc) of the stoma, the wall of the guard cells (gc) is covered with a heavy deposit of oxidized DAB, indicating peroxidase activity. The cuticle (c) seems to cover the enzyme activity of the outer ledge (ol) $(\times 6000)$.

PLATE 2. Here the infection peg (ip) of the fungus secms unaffected by the peroxidase activity on the guard cells $(\times 5950)$.

Plate 3. In a few instances, peroxidase activity was observed in the infection peg (ip) of the fungus $(\times 5950)$.

Plate 4. Non-median section through a haustorial mother cell (hmc) invading the host. The haustorial mother cell seems to dent the host cell wall. Here the cell wall peroxidase activity is very weak. However, on the wall of the penetration peg $(\mathrm{pp})$, strong peroxidase activity is observed $(\times 13600)$.

Plate 5. Cross-section of the haustorial neck (hn) and the haustorial body (ha) with its sheath. Peroxidase activity on the wall of the haustorial neck is evident $(\times 18200)$.

Plate 6. Longitudinal section of the haustorial neck (hn). The peroxidase activity covers about two-thirds of the haustorial neck. There is no continuity between peroxidase activity on the cell wall (wp) and the neck (wp) ( $\times 22500)$.

PLATE 7. Infection hypha (ih), haustorial mother cell (hmc) and the complete haustorium (ha). One nucleus is just migrating into the haustorial body. The layer on the host cell wall (wp) with peroxidase activity seems unaffected after being in contact with the fungus. Peroxidase activity on the haustorial neck is evident. Cytochrome oxidase activity can be seen on the mitochondrial membranes $(\times 12000)$.

Plate 8. Golgi bodies $(g)$ around the body of the haustorium, with cisternae filled with peroxidase. On the vacuole membrane, peroxidase activity was regularly observed $(\times 28200)$.

Plate 9. The Golgi bodies ( $\mathrm{g}$ ) secreted vesicles (arrow) bordered by peroxidase activity. Some activity was also evident on the rough endoplasmic reticulum (er) lying nearby $(\times 40500)$.

Plate 10. Vesicles with enzyme activity (arrows) seem to be secreted towards the partly invaginated sheath (s) of the haustorium (ha) $(\times 23600)$.

Plate 11. Peroxidase activity on the nuclear (nu) envelope and on the rough endoplasmic reticulum (cr). Cytochrome oxidase activity (peroxidatic) is evident on the mitochondrial membranes in the haustorium (ha) $(\times 24300)$.

Plate 12. An intact haustorium in a cell with cytoplasm completely filled with a dense deposit of oxidized DAB. Note that plastids of the host show no deposit $(\times 25500)$. 


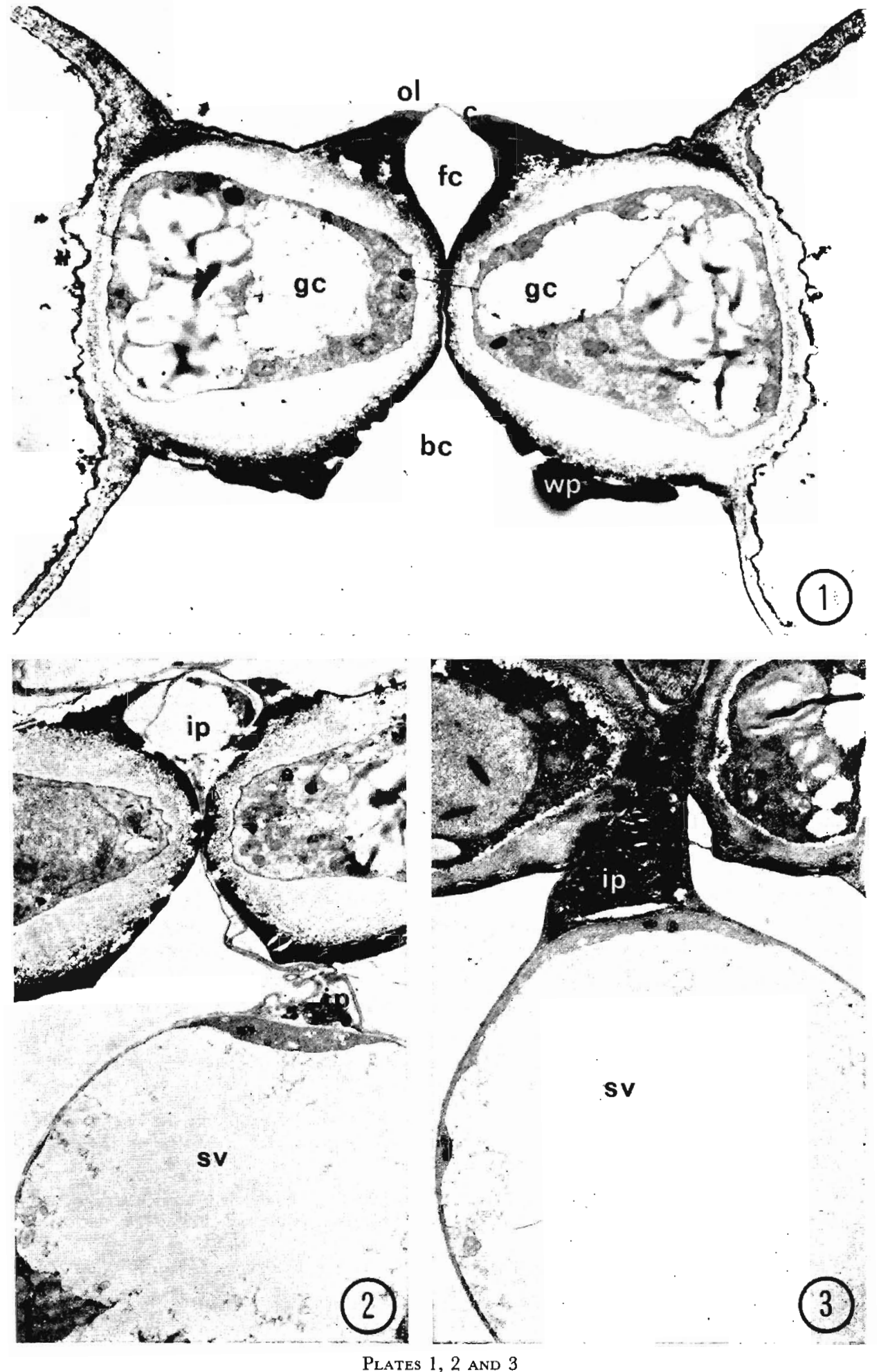



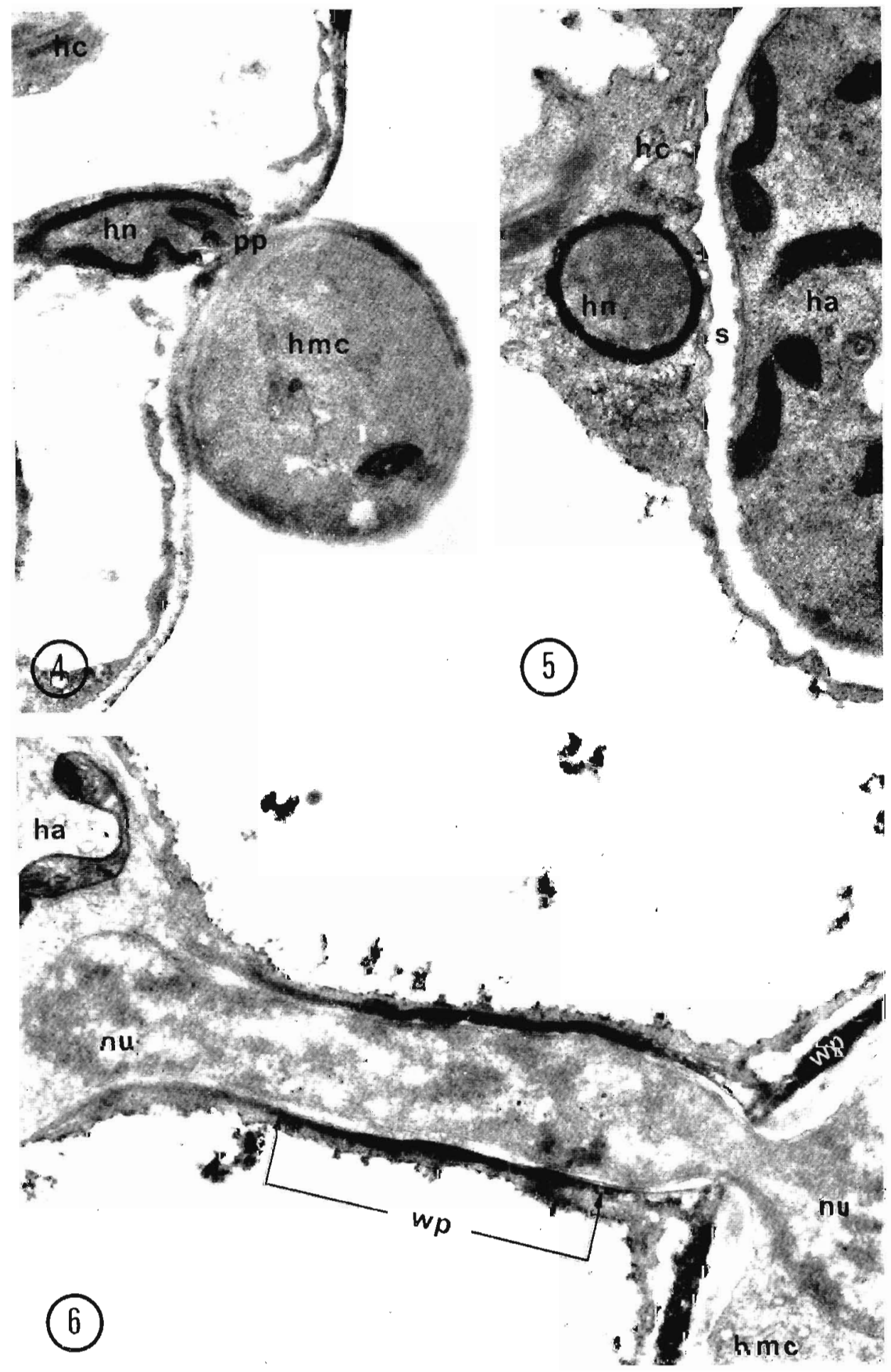

Plates 4, 5 And 6 


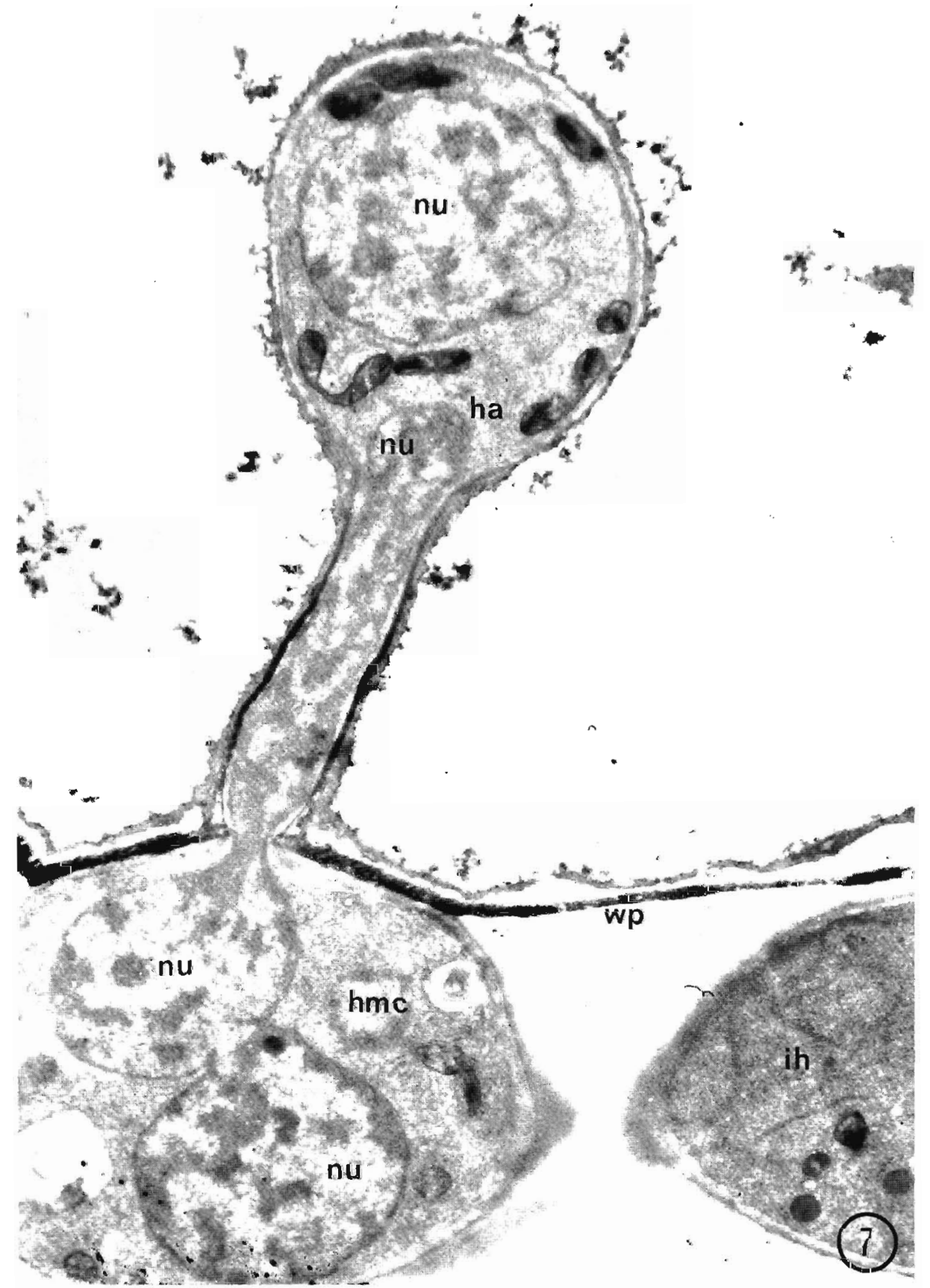

Plate 7 

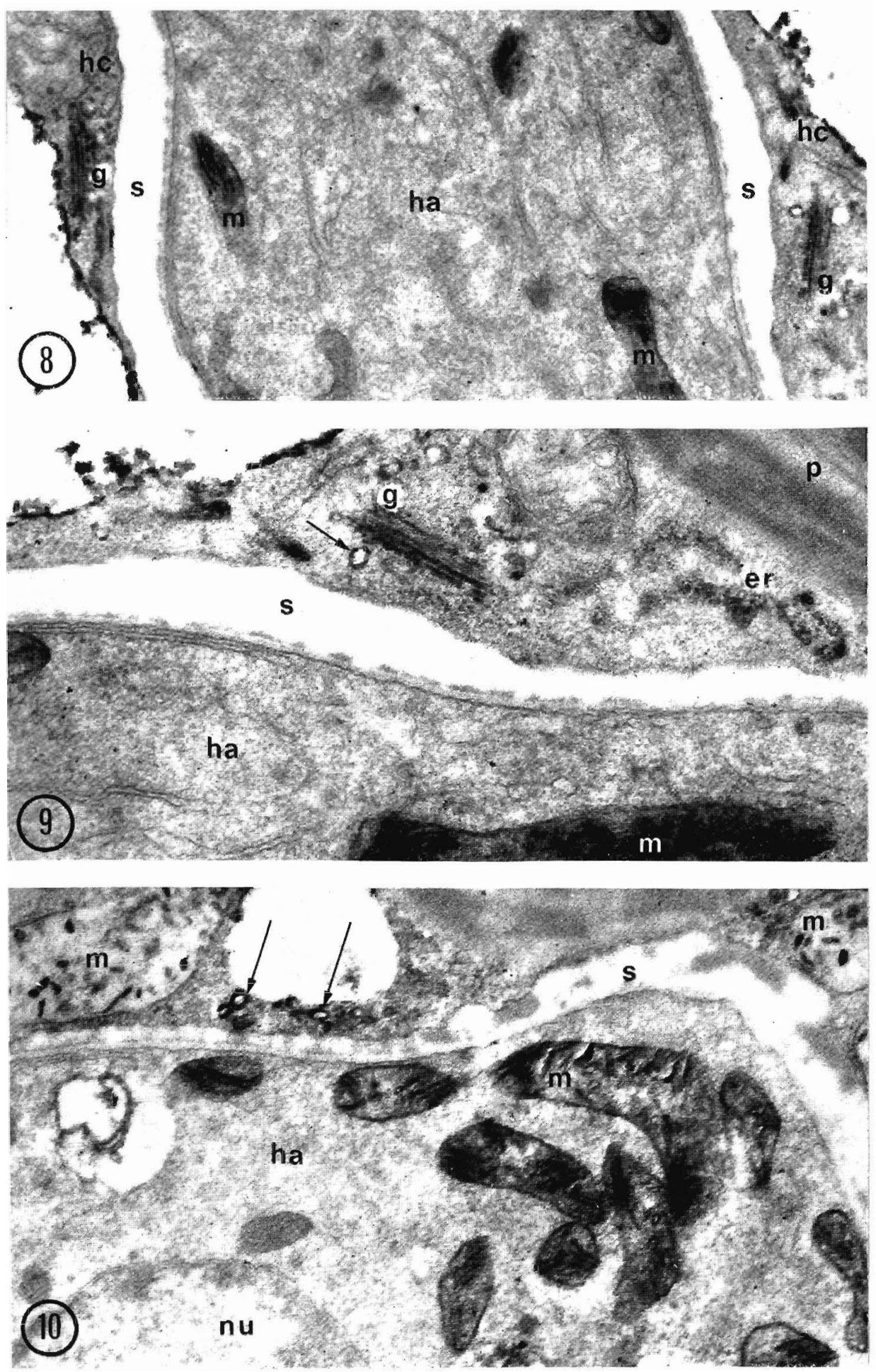

Plates 8, 9 and 10 

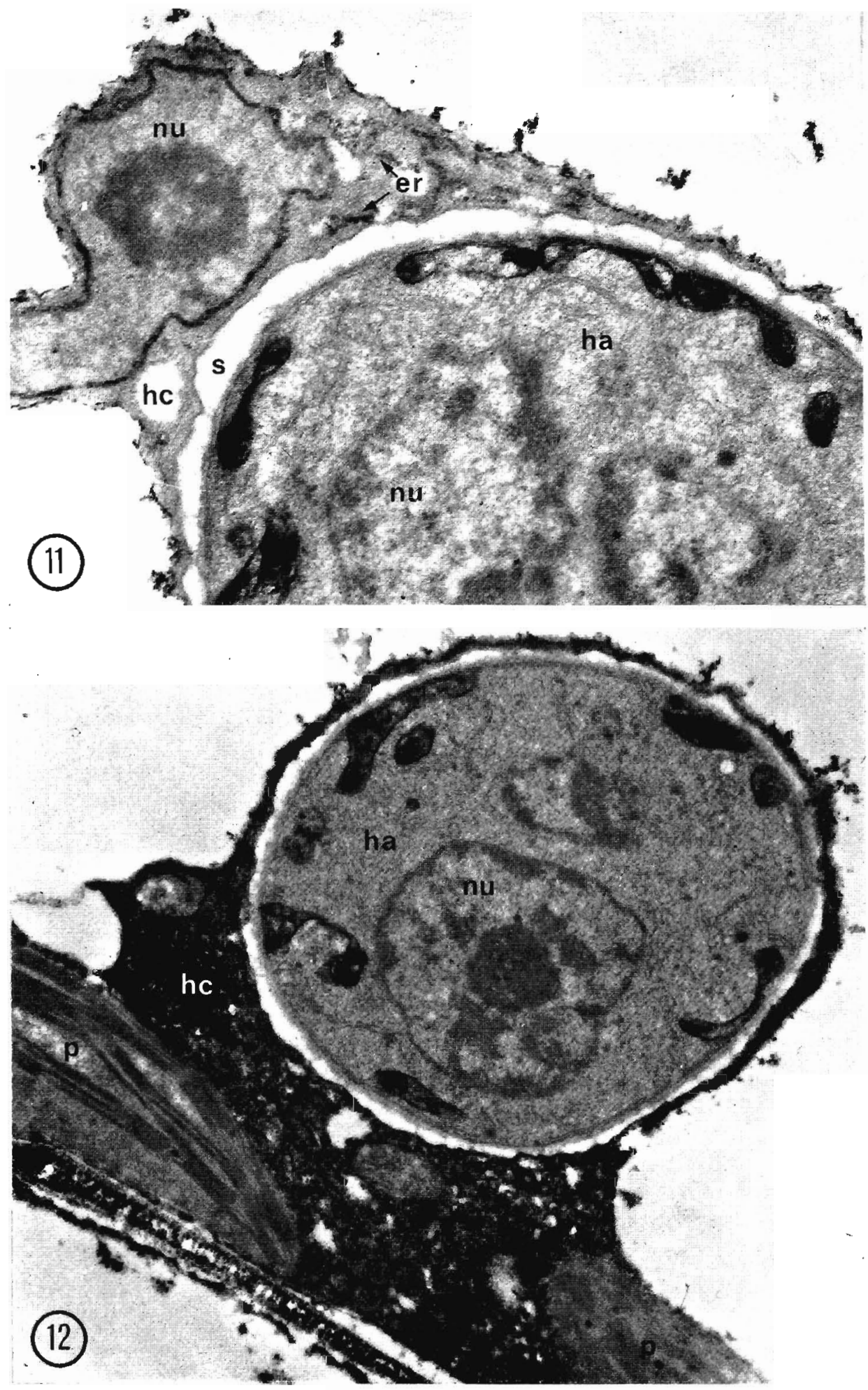

Plates 11 and 12 


\section{DISCUSSION}

The localization of enzyme activities by means of DAB is presumably brought about by the oxidation of $\mathrm{DAB}$ to a polymeric form which, after interaction with $\mathrm{OsO}_{4}$, gives an electron dense precipitate that can be demonstrated with the light- and electron-microscope [30]. During this study care was taken to avoid a more or less specific adsorption of auto-oxidized DAB to heme proteins [13]. Only colourless incubation media were used and incubation was made in the dark since autooxidation may happen in an illuminated laboratory (unpublished results). Care was also taken to avoid diffusion artifacts [5]. Thus, we observed no DAB deposit in the cells after heat treatment of the tissue or omission of $\mathrm{H}_{2} \mathrm{O}_{2}$ from the incubation media.

After incubation in different $\mathrm{DAB}$ media, peroxidase activity has been demonstrated cytochemically in a wide variety of plants [see $8,11,25$ and the references therein]. The activity of this enzyme is characterized by its insensitivity to the differing $\mathrm{pH}$ levels of the media and longer fixation of material. But it can be inhibited by $\mathrm{KCN}$ or heat treatment. Omission of $\mathrm{H}_{2} \mathrm{O}_{2}$ also prevents staining $[11,12,20]$.

After incubation in alkaline media, catalase can be demonstrated by its peroxidatic activity in peroxisomes. In some microorganisms such as algae [7] and in bean rust $[18]$, the molecular conformation of catalase seems considerably more stable in alkali compared to the enzyme of higher organisms [14]. Therefore it was not possible to demonstrate catalase in the fungus. In beans, catalase (peroxidatic) activity is characterized by its sensitivity to aminotriazole [see reference in 18].

In incubation media with acid or neutral $\mathrm{pH}$ and low $\mathrm{H}_{2} \mathrm{O}_{2}$ concentrations, enzyme activity can be demonstrated on mitochondrial membranes $[25,26]$. This activity may be due to a reduction of cytochrome $c$ by DAB [14]. In the absence of $\mathrm{H}_{2} \mathrm{O}_{2}$ from the medium, Seligman et al. [30.] called this cytochrome oxidase activity. In the presence of low $\mathrm{H}_{2} \mathrm{O}_{2}$ concentrations, they prefer to speak of peroxidative activity of heme protein [31]. In previous papers $[18,20]$, we called the activity on mitochondrial membranes cytochrome oxidase (peroxidatic) activity.

Enzyme activities in healthy bean tissue have been described [20]. During bean rust infection of the cell, the most obvious reaction is the peroxidase activity at the penetration site of the fungus along the haustorial neck. After treatment with inhibitors in the different incubation media, this enzyme activity was similar to that of the wall peroxidases. But no morphological continuity between the cell wall peroxidase and the peroxidase on the haustorial neck could be detected. Obviously, the peroxidase activity at the penetration site of the haustorium represents a local reaction during the interaction of host and parasite. Since the enzyme activity was observed between the plasma membrane of the host and parasite respectively, it was not possible to conclude, from these results, whether the host or the parasite contribute to this activity. Since we could not detect peroxidase activity in the fungus, it might be speculated that the enzyme is produced by the host and that it probably influences the penetration process of the fungus.

Around the body of the haustorium, peroxidase activity is demonstrated on the rough endoplasmic reticulum and in the Golgi bodies lying nearby. The question may arise whether peroxidase is being synthesized in the endoplasmic reticulum and 
secreted by the Golgi bodies towards the haustorium. Golgi bodies are known to be involved in cell wall synthesis $[24,29]$. The vesicles, which arise from Golgi bodies, sometimes have membranes with peroxidase activity [12]. This activity is probably involved in the oxidative polymerization of precursors to form the lignin complex [35]. Peroxidase also influences the metabolism of auxin [28]. It is not certain what rôle the peroxidase around the haustorium plays. But it obviously influences the formation of the haustorial sheath and it is proposed that the enzyme might be synthesized on the ribosomal endoplasmic reticulum and secreted by the Golgi bodies towards the sheath.

The envelopes of some nuclei showed peroxidase activity. This is not an unfamiliar finding in growing parts of plants, such as root tips [25], and might be an indication of metabolic activity in the infected cell.

Obvious differences could be seen when these early results are compared with our previous study of bean tissue, made 3 days after infection [20]. The present study shows much more pronounced activity of peroxidase on ribosomes, and also peroxidase activity in Golgi bodies, and sometimes on the nuclear envelope. It is questionable whether we can compare these results with those obtained with extracts of rust-infected bean tissue, separated by gel electrophoresis [21, 22]. Montalbini [22] reported an increase of some bands during the first day after inoculation. We do not know whether the enzyme activity of the cytoplasm which we observed at different sites around the haustorium corresponds to the enzyme bands reported in the gel and whose activity increases after infection. It is doubtful whether the very localized peroxidase activity at the haustorial neck, which corresponds only to a tiny part of a cell's peroxidase enzymes, could be detected in a gel. However, both studies indicate that during infection of the first bean cell, the metabolism is different than in later stages of infection.

In pea enation mosaic virus infected plants, de Zoeten et al. [4] did not observe different localization of catalase and peroxidase in comparison to healthy tissue. After infection of Lycopersicum roots by Pyrenochaeta lycopersici, Delon [3] observed increased activity of cell wall peroxidases only. In the cytoplasm of infected and uninfected cells, peroxidase activity was observed on the ribosomal endoplasmic reticulum, in Golgi bodies and on the nuclear envelope. Similar observations have been reported in uninfected root tips of other plants $[12,25]$.

I thank Prof. Dr W. H. Fuchs for helpful discussions of the manuscript and Prof. Dr G. Röbbelen and Prof. Dr F. Mayer for the use of their electron microscopes.

\section{REFERENCES}

1. Allen, R. F. (1923). A cytological study of infection of Baart and Kanred wheats by Puccinia graminis tritici. Joumal of Agricultural Research 23, 131-152.

2. Chant, S. R. (1967). Respiration rates and peroxidase activity in virus-infected Phaseolus vulgaris. Experientia 23, 676-677.

3. Delon, R. (1974). Localisation d'activités polyphénoloxydasiques et peroxydasiques dans les cellules racinaires de Lycopersicum esculentum parasitées par Pyrenochaeta lycopersici. Phyto. pathologische Zeitschrift 80, 199-208.

4. De Zoeten, G. A., GaARd, G. \& Diez, F. B. (1973). Localization of some heme-containing enzymes in healthy and pea enation mosaic virus-infected plants. Physiological Plant Pathology 3, 159-166. 
5. FAHIMI, H. D. (1973). Diffusion artefacts in cytochemistry of catalase. Fournal of Histochemistry and Cytochemistry 21, 999-1009.

6. Farkas, G. L. \& Stahmann, M. A. (1966). On the nature of changes in peroxidase isoenzymes in bean leaves infected by Southern mosaic virus. Phytopathology 56, 669-677.

7. Gerhardt, B. \& Berger, C. (1971). Microbodies und Diaminobenzidin-Keaktion in den Acetat-Flagellaten Polytomella caeca und Chlorogonium elongatum. Planta 100, 155-166.

8. Hall, J. L. \& Sexton, R. (1972). Cytochemical localisation of peroxidase activity in root cells. Planta 108, 103-120.

9. Hardwick, N. V., Greenwood, A. D. \& Wood, R. K. S. (1971). The fine structure of the haustorium of Uromyces appendiculatus in Phaseolus vulgaris. Canadian Journal of Botany 49, 383-390.

10. Heath, M. C. (1972). Ultrastructure of host and nonhost reactions to cowpea rust. Phytopathology 62, 27-38.

11. Henry, B. W. \& Jensen, T. B. (1973). Peroxidases in tobacco abscission tissue. I. Fine-structural loealisation in cell walls during ethylene-induced abscission. Fournal of Cell Science 13, 591-601.

12. Hepler, P. K., Rice, R. M. \& Terranova, W. M. (1972). Cytochemical localisation of peroxidase activity in wound vessel members of Coleus. Canadian Journal of Botany 50, 977-983.

13. Hirai, K. I. (1971). Comparison between 3,3'-diaminobenzidine and auto-oxidized 3,3'diaminobenzidine in the cytochemical demonstration of oxidative enzymes. Fournal of Histochemistry and Cytochemistry 14, 291-302.

14. Hirai, K. I. (1974). Distribution of peroxidase activity in Tetrahymena pyriformis mitochondria. Fournal of Histochemistry and Cytochemistry 22, 189-202.

15. LitTlefield, L. J. (1972). Development of haustoria of Melampsora lini. Canadian Fournal of Botany 50, 1701-1703.

16. LitTlefield, L. J. \& BRACKer, C. E. (1972). Ultrastructural specialisation at the host-pathogen interface in rust-infected flax. Protoplasma 74, 271-305.

17. Mendgen, K. (1973). Peroxidase activity at the haustorial neck in varieties of bean resistant and susceptible to bean rust. 2nd International Congress of Plant Pathology, Minneapolis.

18. Mendgen, K. (1973). Microbodies (glyoxysomes) in infection structures of Uromyces phaseoli. Protoplasma 78, 477-482.

19. Mendgen, K. (1973). Feinbau der Infektionsstrukturen von Uromyces phaseoli. Phytopathologische Zeilschrift 78, 109-120.

20. MENDGen, K. \& Fuchs, W. H. (1973). Elektronenmikroskopische Darstellung peroxydatischer Aktivitäten bei Phaseolus vulgaris nach Infektion mit Uromyces phaseoli lypica. Archiv für Mikrobiologie 88, 181-192.

21. Montalbini, P. \& Marte, M. (1972). Relatione tra perossidasi, catecolo ossidasi e catalasi in foglie di faglio infette da Uromyces phaseoli (Pers.) Wint., in rapporto alla resistenza ed alla suscettibilità. Phytopathalogia mediterranea 11, 37-41.

22. Montalbini, P. (1972). Peroxidase isoenzymes in susceptible and resistant host parasite complexes of Phaseolus vulgaris and Uromyces phaseoli. Acta Phytopathologica Acddemiae scientiarum hungaricae $7,41-45$.

23. Novikoff, A. B. \& Goldfischer, S. (1969). Visualisation of peroxisomes (microbodies) and mitochondria with diaminobenzidine. Joumal of Histochemistry and Cytochemistry 17, 675-680.

24. Pickett-Heaps, J. D. (1967). Further observations on the Golgi apparatus and its functions in cells of the wheat seedling. Journal of Ultrastructure Research 18, 287-303.

25. Poux, N. (1972). Localisation d'activités enzymatiques dans le méristème radiculaire de Cucumis sativus L. IV. Réactions avec la diaminbenzidine mise en évidence de peroxysomes. Fournal de Microscopie 14, 183-218.

26. Roels, F. (1974). Cytochrome $\mathrm{c}$ and cytochromeoxidase in diaminobenzidine staining of mitochondria. Journal of Histochemistry and Cytochemistry 22, 442-446.

27. Rudolph, K. \& Stahmann, M. A. (1966). Multiple hydrolases in bean leaves (Phaseolus vulgaris L.) and the effect of halo blight diseases caused by Pseudomonas phaseolicola (Burkh.) Dowson. Plant Physiology 41, 389-394.

28. Schneider, E. A. \& Wightman, F. (1974). Metabolism of auxin in higher plants. Annual Review of Plant Physiology 25, 487-513.

29. SchNepf, E. (1969). Sekretion und Exkretion bei Pflanzen. In Protoplasmalologia, Vol. VIII/8. Springer-Verlag, Wien, New York.

30. Seligman, A. M. Karnovskx, M. J., Wasserkrug, H. L. \& Hanker, J. S. (1968). Nondroplet ultrastructural demonstration of cytochrome oxidase activity with a polymerizing osmiophillic reagent, diaminobenzidine (DAB). Joumal of Cell Biology 38, 1-4. 
31. Seligman, A. M., Shannon, W. A., Hoseino, Y. \& Plapinger, R. E. (1973). Some important principles in 3-3'diaminobenzidine ultrastructural cytochemistry. Journal of Histochemistry and Cytochemistry 21, 756-758.

32. Skipp, R. A. \& SAmborski, D. J. (1974). The effect of the Sr6 gene for host resistance on histological events during the development of stem rust in near isogenic wheat lines. Canadian Journal of Botany 52, 1107-1115.

33. Solymosy, F., Szirma1, J., Beczner, L. \& Farkas, G. L. (1967). Changes in peroxidase isoenzymes patterns induced by virus infections. Virology 32, 117-121.

34. Spurr, A. R. (1969). A low viscosity Epoxy resin embedding medium for electron microscopy. Journal of Ultrastructure Research 26, $31-43$.

35. Stafford, H. A. (1974). The metabolism of aromatic compounds. Annual Review of Plant Physiology 25, 459-486.

36. Staples, R. C. \& Stahmann, M. A. (1964). Changes in proteins and several enzymes in susceptible bean leaves after infection by the bean rust fungus. Phylopalhology 54, 760-764. 